9PRXM

Genual Profesi Kesehatan Masyarahat

http://jurnal.bhmm.ac.id/index.php/jpkm

${ }^{\circledR}$ Corresponding Author.

email address : bibitnasrokhatundiniah@gmail.com

Received : 8 Juli 2021 Revised : 10 Agustus 2021 Accepted : 5 Oktober 2021

\title{
Analisis Kualitas Fisik Lingkungan Kerja dengan Keluhan Gangguan Kesehatan pada Petugas Rekam Medis
}

\author{
${ }^{\square 1}$ Bibit Nasrokhatun Diniah, ${ }^{2}$ Avicena Sakufa Marsanti, \\ ${ }^{2}$ La'ali' Kirana Dzakyya Salma Herra \\ ${ }^{1}$ STIKES Kuningan, Indonesia \\ ${ }^{2}$ STIKES Bhakti Husada Mulia, Indonesia
}

\begin{abstract}
ABSTRAK
Tujuan penelitian adalah mengetahui Kualitas Fisik Lingkungan Kerja dengan keluhan gangguan kesehatan petugas rekam medis bagian penyimpanan di UPTD Puskesmas Banjarejo Kota Madiun. Jenis penelitian ini menggunakan pendekatan deskriptif kualitatif. Teknik pengumpulan data yang digunakan adalah wawancara, observasi dan kuisioner. Populasi dan Sampel dalam penelitian ini adalah seluruh petugas rekam medis dan ruang penyimpanan rekam medis di UPTD Puskesmas Banjarejo Kota Madiun. Hasil penelitian ini menunjukkan bahwa suhu udara dalam ruangan $31,2^{\circ} \mathrm{C}$, Pencahayaan 230 lux, adanya debu di ruang penyimpanan rekam medis, ventilasi kurang dari 15\% dan adanya keluhan gangguan kesehatan pada petugas rekam medis. Perlu adanya perbaikan secara fisik ruangan untuk mencegah munculnya Sick Building Syndrome pada petugas rekam medis serta memberikan penyuluhan tentang pentingnya menjaga kualitas fisik lingkungan di tempat kerja.
\end{abstract}

Kata kunci: Petugas Rekam Medis, Fisik Lingkungan, Keluhan Gangguan Kesehatan

Analysis of the Physical Quality of the Work Environment with Complaints of Health Problems in Medical Record Personel

\begin{abstract}
The purpose of the study was to find out the Physical Quality of the Work Environment with complaints of health problems of medical record officers in the storage section at UPTD Banjarejo Health Center in Madiun City. This type of research uses a qualitative descriptive approach. The data collection techniques used are interviews, observations and questionnaires. The population and samples in this study are all medical record officers and medical record storage rooms at UPTD Banjarejo Health Center in Madiun City. The results of this study showed that indoor air temperature was $31.2{ }^{\circ} \mathrm{C}$, Lighting 230 lux, the presence of dust in the medical record storage room, ventilation less than $15 \%$ and complaints of health problems in medical record personnel. There needs to be physical improvement of the room to prevent the appearance of Sick Building Syndrome in medical record personnel and provide counseling on the importance of maintaining the physical quality of the environment in the workplace.
\end{abstract}

Kata kunci: Medical Record Personel, Physical Environment, Complaints of Health Disorders.

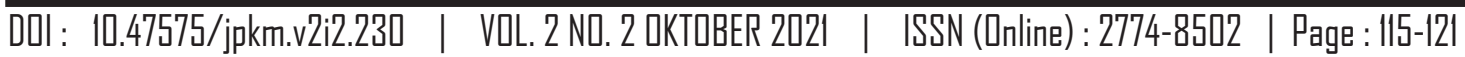




\section{PENDAHULUAN}

Puskesmas merupakan fasilitas pelayanan kesehatan masyarakat tingkat pertama dan memprioritaskan pekerjaan promosi dan pencegahan di fasilitas pelayanan kesehatan dalam rangka mencapai derajat kesehatan masyarakat tertinggi di wilayah kerjanya (Permenkes RI No.75 Tahun 2014). Dalam melaksanakan kegiatannya, puskesmas didukung oleh sebagaian unit ataupun kementrian, salah satunya merupakan rekam medis. Dalam Peraturan Menteri Kesehatan RI No.75 Pasal 7 Tahun 2014 tentang Pusat Kesehatan Masyarakat telah disebutkan jikalau puskesmas wajib melakukan rekam medis.

Menurut Pasal I Permenkes RI No.269 / MENKES / PER/III/ 2008, rekam medis adalah berkas yang memuat catatan dan dokumen mengenai identitas pasien, pemeriksaan, pengobatan, tindakan dan pelayanan lain yang telah diberikan kepada pasien. Pengelolaan rekam medis terdiri dari proses identifikasi pasien, pencatatan data diri pasien, assembling, coding, indexing serta penyimpanan rekam medis. Penyimpanan rekam medis ialah aktivitas yang dilakukan untuk melindungi rekam medis dari kehancuran fisik serta isi dari rekam medis. Penyimpanan rekam medis atau filing ialah unit kerja rekam medis yang diakreditasi oleh Kementrian Kesehatan yang berperan sebagai tempat pengaturan serta penyimpanan dokumen atas dasar sistem penyusunan tertentu atas dasar prosedur yang berlaku, sehingga jika diperlukan sewaktuwaktu dapat menyajikan secara tepat dan tepat (Farlinda, Rinda, \& Rahmadani, 2019).

Proses penyimpanan rekam medis memiliki resiko gangguan pada kesehatan petugas. Contohnya tidak menggunakan alat pelindung diri secara lengkap, seperti masker, faceshiled, gown medis dan handscoon. Sehingga petugas lebih rentan terkena bakteri dan virus, gangguan kesehatan seperti sesak napas dikarenakan terlalu banyak debu yang terhirup, pegalpegal karena sering mengangkat banyak rekam medis.

Ruangan penyimpanan rekam medis di UPTD Puksesmas Banjarejo Kota Madiun Kota Madiun memiliki luas ruangan yang sempit, yaitu kurang lebih sebesar 4x2,8 dan memiliki empat buah rak yang penuh dengan rekam medis pasien. Sarana di ruang penyimpanan rekam medis masih kurang, hal ini dibuktikan bahwa tidak adanya Air Conditioner (AC) dan hanya ada satu buah kipas angin yang jarang difungsikan. Menurut Permenaker No.5 Tahun 2018 bahwa suhu kering di ruangan adalah $23^{\circ} \mathrm{C}-26^{\circ} \mathrm{C}$. Sedangkan suhu ruang penyimpanan di UPTD Puksesmas Banjarejo Kota Madiun yang telah diukur menggunakan thermometer sekitar $28^{\circ} \mathrm{C}$, sehingga suhu tersebut melampaui suhu yang ideal. Akibatnya petugas kurang nyaman berada di ruang penyimpanan karena sering mengalami kepanasan saat melakukan pekerjaannya di ruang penyimpanan rekam medis. Keadaan ini serupa dengan jurnal yang berjudul Analisis Kejadian Missfile Berkas Rekam Medis Rawat Jalan di Puskesmas Bangsalsari bahwa ruangan penyimpanan di Puskesmas Bangsalsari sempit dan tidak adanya sarana Air Conditioner (AC) dan ventilasi yang cukup mengakibatkan petugas kurang produktif dalam bekerja (Wati \& Nuraini, 2019).

Debu merupakan faktor kimia yang dapat menyebabkan penyakit, seperti gangguan pada pernapasan. Di ruang penyimpanan rekam medis UPTD Puksesmas Banjarejo Kota Madiun memiliki ruangan yang cukup terbuka, seperti jendela dan pintu yang tidak pernah ditutup. Selain itu, ruangan tidak pernah dibersihkan jika ruangan masih terlihat bersih. Sehingga menimbulkan adanya debu di dokumen. Hal ini serupa dengan jurnal yang membahas mengenai banyaknya debu di ruang penyimpanan di UPTD Puskesmas Masaran II Kabupaten Sragen dikarenakan tidak adanya alat penghisap debu, kemoceng dan kamper (Pujihastuti \& Rohmadi, 2020).

Selain itu, pencahayaan di ruangan penyimpanan rekam medis sangat dibutuhkan oleh pekerja agar dapat bekerja secara produktif dan nyaman. Tingkat pencahayaan rata-rata di ruang penyimpanan rekam medis (filing) adalah 200 lux (PERMENKES RI No.43 Tahun 2019).

Mengingat kualitas fisik lingkungan kerja, maka penulis melakukan penelitian tentang "Analisis Kualitas Fisik Lingkungan Kerja Dengan Keluhan Gangguan Kesehatan Pada Petugas Rekam Medis". Rumusan masalah penelitian ini yaitu bagaimana analisis kualitas fisik lingkungan kerja dengan 
keluhan gangguan kesehatan pada petugas rekam medis? Tujuan Penelitian adalah untuk Menngidentifikasi Kualitas Fisik Lingkungan Kerja dengan Keluhan Gangguan Kesehatan pada Petugas Rekam Medis.

\section{METODE PENELITIAN}

Metode penelitian dalam penelitian ini yaitu deskriptif kualitatif, dengan populasi dan sampel yaitu seluruh petugas rekam medis di UPTD Puksesmas Banjarejo Kota Madiun sebanyak 4 petugas.

\section{HASIL DAN PEMBAHASAN Suhu Udara}

Dari hasil observasi menggunakan alat thermometer pada pukul 11.00 WIB, di ruang penyimpanan rekam medis di UPTD Puskesmas Banjarejo Kota Madiun didapatkan suhu udara ruangan mencapai $31,2^{\circ} \mathrm{C}$.

Hal ini selaras dengan penelitian (Mathar, Nurlina, \& Puspa, 2019), yang menyatakan bahwa suhu udara di ruang penyimpanan rekam medis mencapai $29-30{ }^{\circ} \mathrm{C}$ sehingga menyebabkan ruangan terasa panas. Hal ini tidak sesuai dengan teori, bahwa suhu normal untuk ruang kerja adalah $23^{\circ} \mathrm{C}-26^{\circ} \mathrm{C}$ (Permenaker No.5 Tahun 2018). Menurut peneliti, ruang penyimpanan rekam medis di UPTD Puskesmas Banjarejo Kota Madiun terasa panas karena ruangan terlalu sempit dan banyaknya barang. Untuk menjaga suhu ruangan tetap normal, perlu adanya alat pengukur suhu ruangan. Selain itu dapat mempelebar ruangan dan mengatur tata letak ruangan dengan menambah alat pending ruangan yang dapat memberikan kenyamanan. Sebab, ruangan dengan sirkulasi udara yang baik dapat menyebabkan suhu udara lebih terasa segar.

\section{Pencahayaan}

Dari hasil observasi mengenai pencahayaan di ruang penyimpanan rekam medis UPTD Puskesmas Banjarejo Kota Madiun pada pukul 12.00 WIB bahwa terdapat 1 buah lampu berwarna putih terang yang berada di tengah atap ruangan. Intensitas cahaya yang berkisar sekitar 230 lux yang diukur menggunakan alat lux meter. Selain itu, terdapat cahaya sinar matahari yang masuk melalui jendela ruang penyimpanan rekam medis. Sehingga, petugas dapat membaca tulisan dengan jelas dan dapat mengambil dan meletakkan rekam medis dengan tepat di rak penyimpanan.

Pencahayaan yang tidak sesuai dapat menyebabkan kelelahan pada mata dan silau yang menyebabkan ketidaknyamanan penglihatan dan biasanya ditimbulkan dari sumber cahaya yang terlalu terang atau tidak terlindungi dengan baik. Menurut Permenkes RI No.48 Tahun 2016 bahwa pencahayaan alam maupun buatan diupayakan agar tidak menimbulkan kesilauan dan memiliki intensitas sesuai dengan kebutuhan. Tingkat pencahayaan di ruang penyimpanan rekam medis adalah 200 lux (Permenkes RI No.43 Tahun 2019).

Dari hasil penelitian, peneliti beropini bahwa di ruang penyimpanan rekam medis UPTD Puskesmas Banjarejo Kota Madiun terdapat jendela yang tidak terdapat selambu sehingga sinar matahari dapat masuk kedalam ruangan

\section{Debu}

Berdasarkan hasil observasi didapati bahwa di ruang penyimpanan rekam medis bagian penyimpanan UPTD Puskesmas Banjarejo Kota Madiun terdapat adanya debu di map rekam medis,rak rekam medis, lantai ruangan dan dinding ruang penyimpanan rekam medis. Petugas menyatakan bahwa di ruang penyimpanan rekam medis terdapat banyak debu karena ruangan jarang dibersihkan. Akibatnya petugas pernah mengalami batuk kering dan gatal-gatal karena terpapar oleh debu. Hal ini sesuai dengan penelitian (Santoso \& Sugiarsi, 2017) yang menyatakan bahwa banyaknya debu di ruang penyimpanan rekam medis yang dapat menyebabkan gangguan kesehatan seperti sesak nafas, alergi dan batuk.

Menurut peneliti, debu yang terlalu banyak di ruang penyimpanan rekam medis membuat ruangan terlihat lebih kotor dan kurang nyaman. Hal ini dapat diminimalisir dengan membersihkan ruangan maksimal 3 hari sekali atau dapat membuat jadwal kebersihan untuk petugas rekam medis, selain itu menyediakan alat penyedot debu, kemoceng, sapu dan lainnya.

\section{Ventilasi}

Dari hasil observasi menggunakan alat rollmeter di ruang penyimpanan rekam medis 
UPTD Puskesmas Banjarejo Kota Madiun diperoleh hasil pengukuran luas lubang angin sebesar 0,58 dan luas lantai sebesar 11,2 . Maka dapat disimpulkan jumlah bukaan ventilasi kurang dari $15 \%$ terhadap luas lantai yang membutuhkan ventilasi. Hasil pengukuran luas lantai dan standar teori bukaan ventilasi Jumlah bukaan ventilasi alami tidak kurang dari $15 \%$ terhadap luas lantai ruang yang membutuhkan ventilasi (Permenkes RI No.43 Tahun 2019). Menurut Permenkes RI No.43 Tahun 2019 ventilasi dapat berupa ventilasi alami dan atau ventilasi buatan. Dari penelitian (Fatma, 2015) menyatakan bahwa ventilasi yang berada di ruang penyimpanan rekam medis belum berfungsi dengan baik sehingga mengakibatkan sirkulasi udara yang kurang baik. Dari hasil penelitian, peneliti beropini bahwa ruang penyimpanan rekam medis di UPTD Puskesmas Banjarejo terlalu sempit, selain itu jendela yang selalu tertutup mengkibatkan sirkulasi udara kurang. Hal ini dapat diatasi dengan penambahahan exhaust, menambah jendela agar pertukaran udara lebih baik.

\section{Gangguan Kesehatan}

Dari hasil kuisioner dengan teknik wawancara kepada petugas rekam medis bagian penyimpanan di UPTD Puskesmas Banjarejo Kota Madiun diperoleh gangguan kesehatan yang dialami petugas rekam medis bagian penyimpanan sebagai berikut (Tabel 1).

Dari tabel 1 terdapat 2 petugas rekam medis bagian penyimpanan yang menjawab Ya yaitu mengalami gangguan pendengaran dengan presentase $50 \%$ dan terdapat 2 petugas rekam medis bagian penyimpanan yang menjawab Tidak yaitu tidak mengalami gangguan pendengaran dengan presentasi $50 \%$. Terdapat 1 petugas penyimpanan rekam medis yang mengalami gangguan pernapasan dengan presentase $25 \%$ dan yang tidak mengalami gangguan pernapasan sebanyak 3 petugas dengan presentase 75\%. 1 petugas rekam medis bagian penyimpanan yang menjawab Ya yaitu mengalami gangguan pada mata dengan presentase $25 \%$ dan 3 petugas penyimpanan rekam medis yang tidak mengalami gangguan kesehatan dengan presentase $75 \%$.

Tabel 1

Hasil Gangguan Kesehatan pada Bahaya Fisik Petugas Rekam Medis Bagian Penyimpanan di UPTD Puskesmas Banjarejo Kota Madiun

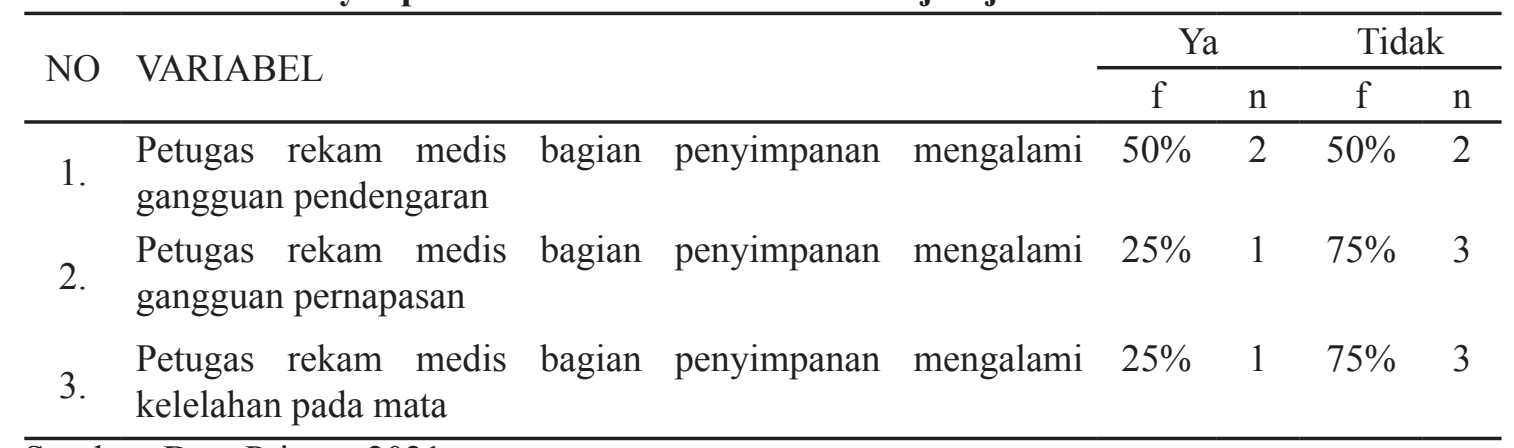

Tabel 2

Hasil Gangguan Kesehatan pada Bahaya Biologi Petugas Rekam Medis Bagian Penyimpanan di UPTD Puskesmas Banjarejo Kota Madiun

\begin{tabular}{llcccc}
\hline \multirow{2}{*}{ NO } & \multirow{2}{*}{ VARIABEL } & \multicolumn{2}{c}{ Ya } & \multicolumn{2}{c}{ Tidak } \\
\cline { 2 - 5 } & & $\mathrm{f}$ & $\mathrm{n}$ & $\mathrm{f}$ & $\mathrm{n}$ \\
\hline 1. & $\begin{array}{l}\text { Petugas rekam medis bagian penyimpanan mengalami gangguan } \\
\text { kesehatan yang disebabkan oleh jamur }\end{array}$ & $25 \%$ & 1 & $75 \%$ & 3 \\
2. & Petugas rekam medis bagian penyimpanan pernah tertular virus & $25 \%$ & 1 & $75 \%$ & 3 \\
\hline
\end{tabular}

Sumber: Data Primer, 2021 
Tabel 3

Hasil Gangguan Kesehatan pada Bahaya Ergonomi Petugas Rekam Medis Bagian Penyimpanan di UPTD Puskesmas Banjarejo Kota Madiun

\begin{tabular}{|c|c|c|c|c|c|}
\hline \multirow{2}{*}{ NO } & \multirow{2}{*}{ VARIABEL } & \multicolumn{2}{|c|}{$\mathrm{Ya}$} & \multicolumn{2}{|c|}{ Tidak } \\
\hline & & $\mathrm{F}$ & $\mathrm{n}$ & $\mathrm{f}$ & $\mathrm{n}$ \\
\hline 1. & $\begin{array}{l}\text { Petugas rekam medis bagian penyimpanan merasa prioritas kerja, } \\
\text { lama kerja dan beban kerja sudah sesuai }\end{array}$ & $75 \%$ & 3 & $25 \%$ & 1 \\
\hline 2. & $\begin{array}{l}\text { Petugas rekam medis bagian penyimpanan merasa fasilitas di ruang } \\
\text { penyimpanan rekam medis sudah lengkap }\end{array}$ & $0 \%$ & 0 & $100 \%$ & 4 \\
\hline 3. & $\begin{array}{l}\text { Petugas rekam medis bagian penyimpanan merasa luas dan layout } \\
\text { ruang penyimpanan rekam medis sudah nyaman }\end{array}$ & $25 \%$ & 1 & $75 \%$ & 3 \\
\hline
\end{tabular}

Sumber: Data Primer, 2021

Tabel 4

Hasil Gangguan Kesehatan pada Bahaya Individu Petugas Rekam Medis Bagian Penyimpanan di UPTD Puskesmas Banjarejo Kota Madiun

\begin{tabular}{|c|c|c|c|c|c|}
\hline \multirow{2}{*}{ NO } & \multirow{2}{*}{ VARIABEL } & \multicolumn{2}{|c|}{ Ya } & \multicolumn{2}{|c|}{ Tidak } \\
\hline & & $\mathrm{f}$ & $\mathrm{n}$ & $\mathrm{f}$ & $\mathrm{n}$ \\
\hline 1. & $\begin{array}{l}\text { Petugas rekam medis bagian penyimpanan memiliki pola hidup yang } \\
\text { sehat }\end{array}$ & $75 \%$ & 3 & $25 \%$ & 1 \\
\hline 2. & Petugas rekam medis bagian penyimpanan memiliki penyakit bawaan & $25 \%$ & 1 & $75 \%$ & 3 \\
\hline 3. & $\begin{array}{l}\text { Petugas rekam medis bagian penyimpanan mengalami pegal linu, sakit } \\
\text { pinggang dan punggung, kesemutan, nyeri atau ngilu pada bagian tubuh } \\
\text { tertentu }\end{array}$ & $75 \%$ & 3 & $25 \%$ & 1 \\
\hline 4. & Petugas rekam medis bagian penyimpanan mengalami stress & $0 \%$ & 0 & $100 \%$ & 4 \\
\hline
\end{tabular}
Sumber: Data Primer, 2021

Dari tabel 2 terdapat 1 petugas yang menjawab Yayaitu pernah mengalami gangguan kesehatan yang disebabkan oleh jamur dan pernah tertular virus dengan presentase $25 \%$. Sedangkan 3 petugas yang lain menjawab Tidak yaitu tidak pernah mengalami gangguan kesehatan yang disebabkan oleh jamur dan tidak pernah tertular virus dengan presentase $75 \%$.

Dari tabel 3 dapat diketahui bahwa terdapat 3 petugas yang merasa prioritas kerja, lama kerja dan beban kerja sudah sesuai dan dapat di presentasekan sebesar $75 \%$ dan 1 petugas tidak merasa prioritas kerja, lama kerja dan beban kerja tidak sesuai, sehingga dapat dipresentasekan sebesar 25\%. Fasilitas di ruang penyimpanan rekam medis menurut seluruh petugas belum lengkap, dengan presentase $100 \%$. Sedangkan luas dan layout ruang penyimpanan rekam medis menurut 1 petugas sudah nyaman dengan presentase $25 \%$ dan 3 petugas merasa tidak nyaman dan dapat dipresentasekan sebesar 75\%.
Dari tabel 4 diketahui bahwa petugas rekam medis bagian penyimpanan sebanyak 3 orang memiliki pola hidup yang sehat dengan presentase $75 \%$ dan 1 petugas penyimpanan rekam medis yang tidak memiliki pola hidup yang sehat. Oleh karena itu, petugas penyimpanan rekam medis yang tidak memiliki penyakit bawaan sebanyak 3 orang dengan presentase $75 \%$ dan 1 orang yang memiliki penyakit bawaan dengan presentase $25 \%$. Saat bekerja, petugas rekam medis bagian penyimpanan sebanyak 3 orang pernah mengalami pegal linu dengan presentase $75 \%$ dan 1 orang petugas penyimpanan rekam medis tidak pernah mengalami gangguan kesehatan seperti pegal linu, sakit pinggang dan punggung, nyeri atau ngilu pada bagian tubuh tertentu dengan presentase $25 \%$. Selama bekerja, petugaspenyimpanan rekam medis bagian penyimpanan tidak mengalami stress dalam pekerjaan, sehingga dapat dipresentasikan sebesar 100\%. 


\section{Tabel 5}

Hasil Gangguan Kesehatan pada Bahaya Psikososial Petugas Rekam Medis Bagian Penyimpanan di UPTD Puskesmas Banjarejo Kota Madiun

\begin{tabular}{|c|c|c|c|c|c|}
\hline \multirow{2}{*}{ NO } & \multirow{2}{*}{ VARIABEL } & \multicolumn{2}{|c|}{$\mathrm{Ya}$} & \multicolumn{2}{|l|}{ Tidak } \\
\hline & & $f$ & $\mathrm{n}$ & $\mathrm{f}$ & $\mathrm{n}$ \\
\hline 1. & $\begin{array}{l}\text { Petugas rekam medis bagian penyimpanan merasa puas dengan } \\
\text { pekerjaan }\end{array}$ & $100 \%$ & 4 & $0 \%$ & 0 \\
\hline 2. & $\begin{array}{l}\text { Petugas rekam medis bagian penyimpanan memiliki konflik } \\
\text { ditempat kerja }\end{array}$ & $100 \%$ & 4 & $0 \%$ & 0 \\
\hline 3. & $\begin{array}{l}\text { Petugas rekam medis bagian penyimpanan merasa dihargai dalam } \\
\text { bekerja }\end{array}$ & $100 \%$ & 4 & $0 \%$ & 0 \\
\hline 4. & $\begin{array}{l}\text { Petugas rekam medis bagian penyimpanan mendapat dukungan dari } \\
\text { rekan kerja maupun atasan }\end{array}$ & $100 \%$ & 4 & $0 \%$ & 0 \\
\hline 5. & $\begin{array}{l}\text { Petugas penyimpanan rekam medis merasa adanya kejelasan tugas } \\
\text { dan tanggungjawab }\end{array}$ & $100 \%$ & 4 & $0 \%$ & 0 \\
\hline
\end{tabular}

Sumber: Data Primer, 2021

Dari tabel 5 dapat diketahui bahwa petugas rekam medis bagian penyimpanan tidak memiliki gangguan kesehatan dengan bahaya psikososial dengan presentase $100 \%$. Berdasarkan hasil penelitian yang dilakukan di UPTD Puskesmas Banjarejo Kota Madiun, terdapat gangguan kesehatan yang dialami petugas penyimpanan rekam medis, diantaranya adalah gangguan kesehatan yang disebabkan oleh bahaya fisik, bahaya biologi, bahaya ergonomi, bahaya individu dan bahaya psikososial. Gangguan kesehatan yang dialami petugas penyimpanan rekam medis disebabkan oleh bahaya fisik meliputi gangguan pendengaran, gangguan pernapasan dan kelelahan pada mata.

Gangguan pendengaran disebabkan karena adanya sound pemanggilan pasien yang bervolume tinggi, sehingga petugas sedikit sulit untuk mendengar ketika sound pemanggilan pasien berbunyi. Gangguan pernapasan yang dialami petugas rekam medis bagian penyimpanan adalah batuk kering yang disebabkan oleh debu. Sedangkan kelelahan pada mata disebabkan karena petugas sering melihat komputer. Gangguan kesehatan yang dialami petugas penyimpanan rekam medis disebabkan oleh bahaya biologi meliputi gatalgatal dan pilek yang disebab kan oleh jamur dan virus ditempat kerja. Bahaya ergonomi menyebabkan petugas kurang nyaman ditempat penyimpanan rekam medis, karena fasilitas yang belum lengkap seperti rak rekam medis yang kurang memadai dan memiliki keterbatasan ruangan yang sempit serta layout yang kurang nyaman selain itu 1 petugas menyatakan bahwa prioritas kerja, lama kerja dan beban kerja belum sesuai dikarenakan jenjang pendidikan yang tidak sesuai dengan profesi yang semestinya.

Gangguan kesehatan akibat bahaya individu adalah petugas mengalami pegalpegal dibagian kaki dan leher saat bekerja, hal ini dikarenakan petugas memiliki pola hidup yang kurang sehat seperti jarang berolahraga serta memiliki penyakit bawaan. Petugas penyimpanan rekam medis tidak memiliki gangguan kesehatan akibat bahaya psikososial, karena petugas memiliki kepuasan dengan pekerjaannya, tidak memiliki konflik di tempat kerja, tidak merasa kurang penghargaan, mendapat dukungan dari rekan kerja dan atasan serta adanya kejelasan dan tanggungjawab saat bekerja. Hal ini sesuai dengan penelitian (Sari \& Wulandari, 2020), bahwa petugas rekam medis bagian penyimpanan mengalami gangguan kesehatan akibat kerja, seperti nyeri pinggang, kesemutan, nyeri punggung, mata berkunang-kunang dan batuk pilek.

Menurut peneliti, gangguan kesehatan yang dialami oleh petugas rekam medis bagian penyimpanan UPTD Puskesmas Banjarejo Kota Madiun disebabkan karena kurang kedisplinannya dalam menggunakan alat pelindung diri dan pekerjaan yang terlalu sering duduk serta melihat komputer sehingga menimbulkan pegal- pegal dan kelelahan pada mata. 


\section{SIMPULAN}

Kualitas Fisik Lingkungan Kerja dilihat dari suhu udara di ruang penyimpanan rekam medis belum sesuai dengan nilai ambang batas yaitu $31,2^{\circ} \mathrm{C}$. Pencahayaan di ruang penyimpanan rekam medis belum sesuai dengan standart yaitu $230 \mathrm{ux}$, masih terdapat adanya debu di ruang penyimpanan rekam medis, ventilasi yang berada di ruang penyimpanan rekam medis belum sesuai dengan standart, dan petugas rekam medis mengalami gangguan kesehatan akibat kerja yaitu batuk kering, mata lelah, gatal-gatal, batuk pilek dan gatal-gatal.

\section{DAFTAR PUSTAKA}

Ali, Montesori Siahaan., R. G., Solikha, D. A., Wikanestri, I., Ardhiantie,., Entos., et al. (2018). Penguatan Pelayanan Kesehatan Dasar di Puskesmas. Jakarta

Crystal, I. D., Ardianto, E. T., \& Farlinda, S. (2020). Analisis Risiko Kerja Petugas Filling Rawat Inap Dengan. J-remi : Jurnal Rekam

Fatma, N. E. (2015). Tinjauan Lingkungan Kerja Yang Menimbulkan Keluhan Subyektif.

Keputusan Menteri Kesehatan Republik Indonesia No : HK.01.07/Menkes/312 $/ 2020$ tentang Standart Profesi Perekam Medis dan Informasi Kesehatan.

Mathar, I. (2018). Manajemen Informasi Kesehatan (Pengelolaan Dokumen Rekam Medis). Yogyakarta: Deepublish.
Mathar, I., Nurlina, \& Puspa. (2019). Perancangan Ulang Tata Kelola Ruang Filling Berdasarkan Ilmu Ergonomi di Puskesmas Banjarejo Kota Madiun. Prosiding Call For Paper SMIKNAS, 177-181.

Redjeki, M.Si., D. (2016). Kesehatan Dan Keselamatan Kerja. JAKARTA: Badan Pengembangan dan Pemberdayaan Sumber Daya Manusia Kesehatan.

Sanah, N. (2017). Pelaksanaan Fungsi Puskesmas (Pusat Kesehatan Masyarakat) Dalam Meningkatkan Kualitas Pelayanan Kesehatan. eJournal Ilmu Pemerintahan, 5(1), 305-314.

Santoso, B.A., \& Sugiarsi, S. (2017). Tinjauan Penerapan Manajemen Resiko. Jurnal Manajemen Informasi Kesehatan Indonesia, 5, 19-26.

Sari, D. A., \& Wulandari, F. (2020). Gangguan Kesehatan Kerja Dan Kecelakaan Pada Petugas Unit Rekam Medis Di Bagian Filing Rumah Sakir Roemani Muhammadiyah Semarang Tahun 2019. Visikes, 18(2), 60-66.

Susanto, E., Endang, R. S., \& Cahyaningsih, R. D. (2019). Keselamatan dan Kesehatan Kerja Pada Penyimpanan Rekam Medis. Jurnal Rekam Medis dan Informasi Kesehatan, 2, 34-38.

WHO. (2009). WHO Guidelines for Indoor Quality: Select Polutants. 